\title{
PIIL PESENGGIRI AS A PEACE CULTURE: A LOCAL WISDOM-BASED RESOLUTION TOWARD LAND CONFLICTS IN MESUJI, LAMPUNG
}

\author{
BUYUNG SYUKRON ${ }^{1}$ \\ RUSMADI² \\ ${ }^{1}$ Institut Agama Islam Negeri Metro Lampung \\ ${ }^{2}$ Universitas Islam Negeri Walisongo Semarang
}

\section{Abstract}

The presence of big companies holding the certificate of cultivation right on lands or hak guna usaha in Mesuji, Lampung has triggered numerous land conflicts. Various efforts have been made, but in fact, they have not been able to resolve the conflicts. A new approach in resolving the conflicts is, thus, needed. This article, using descriptive-qualitative research method, tries to present a new model of resolution of land conflicts in Mesuji, Lampung Province, based on local wisdom called piil pesenggiri, the philosophical values of Lampung people. Piil pesenggiri itself is a sense of self-esteem; it is principles the Lampung people must follow in order to live in dignity. The article argues that the values contained in piil pesenggiri can be used to resolve the land conflicts in Mesuji since they have been inherent in the life of Lampung society. The values are such as juluk adek (principles of success), nemuin yimah (principles of respect), nengah nyappur (principles of equality), and sakai sambayan (principles of cooperation). All those values are a manifestation of peace culture that can be used as a medium of conflict resolution.

Corresponding author; email: ${ }^{1}$ buyungsyukron@gmail.com, ${ }^{2}$ rusmadi@walisongo. ac.id 
Kehadiran perusahaan besar dengan sertifikat hak guna usaha di Kabupaten Mesuji, Lampung telah memicu timbulnya konflik lahan. Berbagai upaya penyelesaian konflik telah banyak dilakukan, akan tetapi belum mampu menyelesaikan konflik. Diperlukan upaya lain yang mampu menawarkan cara dan pendekatan baru di dalam penyelesaian konflik. Dengan menggunakan metode penelitian deksriptif-kualitatif, artikel ini menyajikan model resolusi konflik lahan di Kabupaten Mesuji Provinsi Lampung berbasis kearifan local piil pesenggiri yang merupakan falsafah hidup masyarakat Lampung. Piil pesenggiri memiliki arti harga diri, atau prinsip-prinsip yang harus dianut agar seorang itu memiliki harga diri. Hasil penelitian menemukan bahwa nilai-nilai yang terdapat pada piil pesenggiri dapat dijadikan model resolusi konflik karena nilai-nilai tersebut telah melekat dalam kehidupan masyarakat dan menjadi cara hidup masyarakat Lampung. Nilai-nilai yang terdapat pada piil pesenggiri misalnya juluk adek (prinsip keberhasilan), nemui nyimah (prinsip penghargaan, saling menghargai), nengah nyappur (prinsip kesetaraan), dan sakai sambayan (prinsip kerjasama). Semua nilai-nilai dalam piil pesenggiri merupakan budaya damaiyang dapat dijadikan sebagai media resolusi konflik.

Keywords: conflict resolution; land conflicts; local wisdom; peace culture; piil pesenggiri.

\section{Introduction}

Lampung Province is one area prone to conflicts. Numerous conflicts have occurred in the province, such as conflict among villagers and conflict that involves corporation as the holder of certificate of cultivation right on lands or Hak Guna Usaha (HGU). Many perspectives have been revealed to explain the conflicts, especially in Mesuji, such as an analysis that sees the unrest as part of an investment design for land clearing by utilizing the local socio-political dynamics. In its early step, the con- 
flict is purposely conditioned, so that the area will be assumed to be unsafe. Later, this conditioning is used as the fundamental reason or justification to hold a large security projects by the military.

Basically, the conflict in Lampung Province is not a new phenomenon. The province has plenty historical records related to violences occurring in the land popular with Sang Bumi Ruwa Jurai since the New Order regime. The Tragedi Talangsari in Kampung Talangsari, Rajabasa Lama Village, Metro City, Lampung Tengah, is a clear example. This tragedy involved civilians, radical organization, and military. It killed up to 185 peoples and hundreds of the wounded, and was considered as a form of arrogance of the authority against civil society in the guise of law enforcement. The tragedy contested a clash between the authority and the separatists known as the security disturbing forces on the basis of religious issue. In fact, what really happened is just the opposite. Power and religion are used merely as a political tool to gain specific purposes in the expense of the civilians (Chandra 1992).

The data issued by Kesabangpol Lampung Province in 2015 reveals that the conflicts in 14 regencies or cities are amounted to 130 incidents and consist of many types, i.e. religious/tribal/ ethnical conflict (12 incidents), political conflict (8 incidents), borderline conflict (23 incidents), industrial conflict (4 incidents), agrarian/land conflict (39 incidents), and social conflict (44 incidents). From the given data, we come to know that conflicts specifically triggered by land disputes are amounted to 39 incidents, and one of the land disputes remains unresolved as it involves plantation company and the land owners in Mesuji, Lampung Province. The local residents claim to own the lands since they reside the area through transmigration program initiated by the government. The lands are generally utilized for oil 
palm plantations serving as the source of the family income, including the education cost of their children until university level.

The potentials of land estate in Mesuji gradually invite parties to do investment in a large scale, like oil palm, rubber, acacia, and starch. Some of them even directly open the processing unit of Crude Palm Oil (CPO). Companies that obtain much attention dealing with the plantation are such as PT. Barat Selatan Makmur Investindo (BSMI) in oil palm plantations and PT. Silva Inhutani Lampung (SIL) in the production forest. These two companies obtain the exploitation right of the lands from the government. From this point, land disputes emerged and led to the large-scale conflicts as seen in a conflict that arose on November 10, 2011 between the local residents and PT. BSMI. Another conflict involved the local residents and PT. SIL and has occurred since 1998 until now. The cause is always the same, i.e. the two companies do expansion of lands claimed to be legally owned by the local community.

The presence of large companies holding the certificate of cultivation right on lands (HGU) ultimately triggers land conflicts in Mesuji, such as conflict of land ownership between PT. BSMI and the local community and conflict of forest management in Register 45 between PT. SIL and the local community along with the forest encroachers. Other cases of land conflicts occurred between PT. BSMI and the people of Kampung Nipah Kuning, Kagungan Dalam and Kampung Sritanjung that have resulted in losses of materials large enough for both the local community andthe company (Wibowo 2012). According to a Report from the Tim Pencari Fakta/TPF (Fact-Finding Team) on Mesuji Case, January 16, 2015, land conflict between PT. BSMI has happened since 1994 when the company obtained permission to exploit the area, and the conflict continued to reach its peak in 2011 (precisely in November $8^{\text {th }}-10^{\text {th }} 2011$ ) involving the local residents and PT. BSMI. 
Further, the land conflicts involving the local community, forest encroachers and PT. SIL as the manager of area Register 45 are triggered by the Decree of the Minister of Forestry No.688/ KPTS-II/1991 issued on October 7, 1991 when the Department of Forestry granted a forest concession right to PT. SIL (Silva Inhutani Lampung) of 33,500 Ha. There are two things that become the root of the problem and lead to conflict. First, the Ministerial Decree states that PT. SIL shall allow the people residing in the area to utilize the existing forests. However, in reality, the company does not allow such utilization. Second, the expansion of the forest in Register 45 from 33,500 $\mathrm{Ha}$ to $43,100 \mathrm{Ha}$ is considered to seize the people's lands.

The land conflict between the local community and PT. SIL has happened since 1991 when the company obtained a project permit in Hutan Tanaman Industri (HTI). According to the Report of the Tim Pencari Fakta/TPF (Fact-Finding Team) on Mesuji Case, January 16, 2012, the conflict has occurred since incidents of eviction in 1986-1987. In 1991 until 1997 PT. SIL obtains land control of 43,100 Ha through HTI. However, in 2004, the community demanded their right of an area of 7,000 Ha. In 2010, eviction of the local community by the company occurred and ended in riots. It occurred again in February and September 2011.

Based on the above description of land conflicts that involved PT. BSMI and PT. SIL, it is obvious that the land conflicts are indeed an accumulation of public discontent concerning the companies' actions and policies since they began operating their businesses in the lands. In addition, the conflicts are also caused by the companies' attitude inconsistent with their promise to the community concerning compensation for land acquisition and land tenure that do not correspond with the permits issued by the government. Actually, various efforts to resolve the conflicts 
have been made through meetings between the related parties, academic studies, and field visits. However, these efforts have not been able to resolve the land conflicts until now. ${ }^{2}$ Mediation attempts have even been made by the government, with an agreement that the companies must reimburse the lands they have used. Yet, the compensation has not been paid.

Until now, the land conflicts between the local community and the companies in Mesuji district are still happening. The reason behind this situation is due to less attention of the related parties to resolve their conflicts. There is a deadlock in finding an appropriate form of conflict resolution. The conflicts are of course in desperate need of right resolution in order to avoid larger negative impacts.

This study tries to offer a different approach to deal with the land conflicts, more specifically a model of conflict resolution based on local wisdom known as pill pesenggiri adhered by the local community. The values that can serve as a foothold to resolve the conflicts are such as humanity, solidarity, fraternity, and role modeling. One consideration the local wisdom can serve as a model of conflict resolution is because it is already entrenched in people's lives. Such wisdom is somewhat profane and sacred at the same time. Therefore, it is more easily acceptable by the community.

This in-depth research is a descriptive-qualitative research that employs phenomenological approach. It is aimed to reveal the existing phenomena in the conflict area of Mesuji, both natural and man-made phenomena. Later, it will formulate a model of conflict resolution based on local wisdom, piil pesenggiri. In other words, this study tries to interpret not only the given

\footnotetext{
${ }^{2}$ The research documentation of 2013, data sources: the Mesuji District Governance Section 2013 and the Visit Report of Commission II, DPR RI, Thursday, January 26, 2012.
} 
situation in Mesuji but also the values of local wisdom, piil pesenggiri, followed by the people of Mesuji as a way to develop a model of conflict resolution in the conflict area. The data was collected through observation, interviews and document review of various sources, involving institutions, organizations, and individuals.

\section{Land Conflicts in Mesuji}

The Agrarian Reform Consortium or Konsorsium Pembaruan Agraria (KPA) in 2012 published a report stating that there were 198 cases of land disputes in Indonesia with 156 peasants detained, 55 people injured and maltreated, 25 peasants shot, and 3 people killed. In general, the land conflicts lasted long enough, and they have started since the lands were under the control of local authorities, such as the local leader or tribal chief, group of nobles, and even corporations (Mandel 2016).

Soimin (2008) noted that agrarian conflicts between local communities and companies have occurred many times, such as conflicts between indigenous people and companies (9\%), local community and Perhutani (11\%), farmers and companies $(12 \%)$, and local community and company $(50 \%)$. This data illustrates that conflicts generally occur between communities and outsiders who have interests in the lands, especially economic interests (Soimin 2008).

Susan (2012) stated that when viewed from their form, land conflicts have different dimensions, such as between local community and private or state companies, between peasants and companies, and so on(Susan 2012)(Susan, 2012)(Susan, 2012). Her research findings suggested several causes of land conflicts involving communities, namely: (1) the misuse of land contract by companies in the expense of local communities, (2) the claim over empty lands between companies and peasants, and (3) the 
negligence of land administration by the National Land Agency or Badan Pertanahan Nasional (BPN).

From humanitarian perspective, lands have a multidimensional meaning that makes people try their best to defend the lands whenever their rights are violated. From economic perspective, lands are a means of production that can bring prosperity for mankind. From political perspective, lands help determine a person's position as decision maker in society. From cultural perspective, lands may determine the level of the owner's social status. From transcendental perspective, finally, lands are seen as the essence for people will go back to the land at the end of their life (Nugroho 2001).

Sumardjono maintained that lands as an economic right of individuals have the potentials to create conflicts that can bring impacts on various areas of human life. Usually, land conflicts place the lower class, such as the peasants, as the most disadvantaged parties. This point is easily understandable because they have limited human resources, so that in turn they also do not have a decent income. Their economy suffers because they do not earn enough money to support their family. The Mesuji case is not an exception as the case contested a land dispute between the local community and corporations, i.e. PT. BSMI and PT. SIL. In that case, the local residents strive to keep the lands as the source of their economy (Sumardjono 2008).

Land conflicts between the local community and PT. BSMI ${ }^{3}$

One plantation company that comes to Mesuji is PT. BSMI. Initially, the company proposed a permit of cultivation right on lands through Application Letter No.0007/BSMI/10/94 to manage lands in Mesuji, i.e. plasma plantation of 7,000 $\mathrm{Ha}$ and core

${ }^{3}$ The research documentation of 2017, data sources: the Mesuji District Governance Section 2013 and the Visit Report of Commission II, DPR RI, January 26, 2015. 
plantation land of $10,000 \mathrm{Ha}$ in the village of Kagungan Dalam, Sri Tanjung and Nipah Kuning of Mesuji District to the Regional Government of North Lampung, at that time, Mesuji was not a separate district through regional expansion. Later, this proposal was approved by the Government of North Lampung on October 18, 1994 through the Head of Land Registry No. PLU.22/460-IL/1994 on the Location Permit Granting to PT. BSMI for Oil Palm Plantation with approximately 10,000 $\mathrm{Ha}$ for the core plantation land and 7,000 $\mathrm{Ha}$ for the plasma plantation located in the village of Kagungan Dalam, Sri Tanjung and Nipah Kuning of Mesuji District. The permit is valid for 12 months after issued. ${ }^{4}$

Later, the Land Audit Committee (Committee B) of Lampung Province in its treatise dated November 27, 1996 Number: 09/PPT/KW/1996 concluded that the application of HGU (Cultivation Right on Lands) from PT. BSMI on an area of \pm $10,000 \mathrm{Ha}$ was approved and granted with \pm 9,513.0454 Ha for core plantation land and \pm 7,000 Ha plasma plantation. Then, on June 4, 1997 the State Minister of Agrarian Affairs/Head of BPN (National Land Agency) issued a Decree of HGU No.43/ HGU/BPN/97 on the HGU Granting for 35 years to PT. BSMI, whose office is located in the Municipality of Bandar Lampung, over the land owned by the State of \pm 9513.0454 Ha located in Mesuji, North Lampung Regency. After that, with reference to Decree of the Minister of Agrarian Affairs or Head of BPN, PT. BSMI certified the land to the Land Agency of North Lampung and got the HGU Certificate No. 47 of 1997.

In reality, the land for plasma plantation was not handed over to the local communities to be managed as written in the certificate. On the contrary, it was the company that managed the land. Some lands belonged to the community were even in-

${ }^{4}$ The research documentation of 2017, data sources: the Mesuji District Governance Section 
cluded in the company's claim. Faced with these conditions, the people of Kampung Nipah Kuning, Kagungan Dalam and Sri Tanjung sue the PT. BSMI to provide the land of $\pm 7,000 \mathrm{Ha}$ located in the three villages to be managed by them as it was their rights according to the HGU certificate. The HGU certificate is the reason used by the people to harvest palm oil in the land of plasma plantation controlled by PT. BSMI. As a result, conflicts arise between the local community and the company.

According to the Report from the Tim Pencari Fakta/TPF (Fact Finding Team in Mesuji, 2015, this conflict even killed and hurt some residents in Sri Tanjung and Kagungan Dalam due destructive forces in dealing with the land conflict. The victims are generally shot. In an interview, a resident gave his testimony that the shooting incident against the community on November 10, 2011 has led to a hit in the head: "This incident caused someone shot in the head. None knows who shoots. In addition, I know that a resident suffered a broken leg and was taken to the General Hospital of Menggala".

Conflicts have been increasing with the harvest season and continue to increase over time. In July 2011, PT. BSMI requested security assistance to the police to curb the people who do the "forced harvest" on the palm trees. This action makes the conflict worse as it involves the police. The conflict involving the police has caused the loss of life from the community as a result of being shot. Later, the community protested, causing a major conflict on November 10, 2011.

Land Conflicts between the Community and PT. SIL in Register $45^{5}$

Like the conflict between the local community and PT. BSMI, the root of the conflict between the local community and

${ }^{5}$ The research documentation of 2017, data sources: the Mesuji District Governance Section 
PT. SIL in Register 45 is also associated with the expansion of forest in Register 45 of 33,500 Ha becoming 43,100 Ha. The expansion is considered to take the people's land. The presence of land brokers also increases the conflict tension. The brokers take advantage of the unclear forest expansion in Register 45 by using the issue of tanah adat or the indigenous land. Later, they draw some money from the local community by selling the land to a certain person. In addition, the coming of immigrant communities also complicates the issue. For the immigrant community, also known as moro-moro people, they use the land because they think that the land in Register 45 is being abandoned. They are part of the forest encroachers who manage the land for farming for their livelihood. Until now, they have survived for 13 years and managed an area of 2,444 Ha.

The case of forest encroachment in Register 45 is due to the lack of monitoring from the company as the holder of HGU and from the government in maintaining the area. In addition, the presence of the land brokers also facilitates the coming of the encroachers to occupy the lands. Initially, the brokers try to influence the communities, who do not understand the issue of land status, to sell the lands to them. From them, those lands are then sold to people from outside Mesuji, including the encroachers.

Based on the decree issued by the Ministry of Forestry, the right party to manage forest in Register 45 is PT. SIL to be planted with sengon, rubber and acacia. In 1993, the Register 45 has been designated as Production Forest by the Decree of the Minister of Forestry No. 785/KPTS-II/1993 dated February 22, 1993 with an area of $43,100 \mathrm{Ha}$. This means that there is a land excess when compared to the permit issued by the government beforehand. Meanwhile, the encroachers who have occupied the lands in Register 45 can not show any proof of ownership because they don't use formal proof during the transactions. Further- 
more, if seen from the permits issued by the government, there is an overlapping of licensing. That is, one piece of land may have more than one legal permit. As a result, conflicts dealing with the land ownership occur because of the mismatch among many different permits. ${ }^{6}$

Conflicts in Register 45 for a dozen of years have neglected the basic constitutional rights of citizens as regulated by 1945 on land management for lifesurvival.Besides, thousands of immigrants in the Forest Register 45 also lose their rights concerning identity documents and proper education and health services. This condition helps create another land conflict of different dimension.

\section{Piil Pesenggiri as Peace Culture for Conflict Resolution in Me- suji}

Piil pesenggiri, which means self-esteem, is the Lampung people's philosophy of life. The values contained in piil pesenggiri include juluk adek (principles of success) ${ }^{7}$, nemui nyimah (principles of respect) ${ }^{8}$, nengah nyappur (principles of equality) ${ }^{9}$,

\footnotetext{
${ }^{6}$ Report from the Fact Finding Team (TPF) in Mesuji case, Jakarta, January 16,2012

${ }^{7}$ Juluk or bejuluk means a new name when someone is able to achieve his goals or gain success. Meanwhile, Adek means a title or a new name that is carried. New names are only given to someone who has succeeded in achieving their goals. This principle is a sign that Lampung people always want positive and innovative changes.

${ }^{8}$ Nemui means guests and Nyimah or Simah means polite. This principle is a sign that the people of Lampung always behave politely and respect guests (the immigrants). Therefore, Lampung people are always open to all migrants.

9 Nengah means hard-working, skillful, and motivated. Meanwhile, Nyapur means tolerant and competitive. The word Nengah must be coupled with Nyapur, so that overall they mean that the people of Lampung equip themselves with the ability to navigate life to be used optimally for the prosperity of mankind.
} 
and sakai sambayan (principles of cooperation)..$^{10}$ The principles in piil pesenggiri are adopted and adhered by the people of Lampung, so that they have self-esteem. In fact, this philosophy also inspires the birth of the motto "Sai Bumi Ruwa Jurai" meaning one land two tribes, i.e. the original tribe of Lampung people (Pepadun and Saibatin) and the tribe of new comers (those who come from outside the Lampung province). This motto illustrates that the Lampung people have an openness to accept and live in peace with the immigrants.

The values contained in the piil pesenggiri also reflect the universal values of solidarity. As universal values, they can be easily accepted by people everywhere. Nengah nyappur which means equality, for example, is something that promotes recognition of universal human rights. This universality enables anyone to learn, obey, and practice it. Therefore, if the Lampung people are able to internalize the values contained in piil pesenggiri, they will be able to negate conflicts in their community. In other words, the local wisdom reflected in piil pesenggiri can serve as a medium of conflict resolution. Later, this effort can also be used to revitalize the local wisdom itself in dealing with the various dynamics in the community through the process of contextualization. This process is an integral part of conflict resolution based on local wisdom.

One of the fundamental reasons to develop a conflict resolution model based on local wisdom is that the local wisdom is the life values strongly inherent in people's lives and becomes part of their social identity. In this case, the life values of piil pesenggiri are the identity strongly attached to the Lampung people. This

${ }^{10}$ Sakai or Akai means open and able to accept something that comes from outside. Meanwhile, Sambai or Sumbai (messenger) means giving. Sakai Sambaian means mutual cooperation among the people of Lampung where they live. 
is a new way of conflict resolution. In this context, if a conflict occurs, the local wisdom is believed to be able to identify the conflict based on its causes and to see it from many viewpoints to resolve it. Later, several analyses need to be done to deal with the conflict resolution process, including:

First, core of the conflict. It is the cause of a variety of social distress or deprivation that can no longer be tolerated. The making the deadline for tolerance was usually done because the level or intensity of the deprivation is unbearable, such as the land tenure and agricultural output dominated by a group of people or a specific company, or certain public positions in an area dominated by a particular group.

Second, fuse factors. This factor has existed in every society in the form of, for example, tribal sentiment, feeling, religion, and so on. However, such a sentiment will not turn into a conflict if no one commits provocation.

Third, triggering factors. It is a moment where all the elements mentioned above accumulate and lead to real conflict. The moment can be known in the form of small quarrel or fight between two individuals on the ground of very small problem. Later, this small quarrel becomes a justification for starting the larger conflict (Mudzhar 2003).

Those three aspects can be used to map the land conflicts in Mesuji, mainly to look for the roots and forms of conflicts. As in reality, the core of the conflict is the government's failure to fulfill socio-economic rights of the local community, particularly related to the use of land.

The explanation above gives clear information that the source of the conflict is concerned with the former forest land, known as the Register land. At first, the land is controlled by the state and enables the local community to manage it. This means that the local community have the same right as the business- 
men to use and access the land. But in fact, citizens who use the region of Register 45 are considered to be unlawful, while the businessmen are still free to enter and use the land. From this point, it is clear that inequity of access to land ultimately leads to the emergence of land conflicts.

Heynes stated that conflicts between communities are the result of unjust policy characterizing the dynamics of democracy in Third World countries. The Mesuji case, in this context, is an issue purely related to land policy; it has no relation with multicultural issue based on religion or ethnicity. However, if not solved, the issue can ignite a wider social conflict. In this case, the land policy serves as the fuse factor that may lead to larger social conflicts on the basis of religion and ethnicity. Given this situation, national disintegration in society is also possible. The land conflict in Mesuji, in fact, causes widespread horizontal conflicts, such as burning assets and offices, destructing houses, places of worship, roads, vehicles and others (Heynes 2000).

Therefore, conflict resolution involving potentials or capitals that exist in the community is highly important. The potentials meant here are the values found in local wisdom inherent in the community, i.e. their identity. In this context, piil pesenggiri, which is the identity of people living in Lampung Province, including Mesuji, plays a crucial role in conflict resolution. This makes sense since many approaches used to handle the conflicts have failed. The existing approaches do not satisfy all parties.

The universal values in piil pesenggiri need to be actualized in Mesuji by the conflicting communities and society in general to maintain a peaceful life. This step begins with understanding the values and then popularizing them, not only to the people of Mesuji or Lampung in particular, but also to all society in general. This means that piil pesenggiri should not be distorted only as regional identity, but universal way of life. 
Some initial efforts to resolve land conflicts in Mesuji involving the local wisdom contained in piil pesenggiri are as follows: (1) Scrutinizing the piil pesenggiri's values. This step is done by making an inventory of the universal values in piil pesenggiri, so as to create a standard document of local wisdom. (2) Internalizing and contextualizing the universal values of piil pesenggiri in every facet of people's lives in Lampung. This step requires an integral understanding of people living in Lampung, both the natives and the immigrants. If the immigrants are able to understand the philosophy of life in Lampung and put it into practice, then peaceful society with mutual respect among people in Lampung becomes possible. (3) Disseminating the universal values of piil pesenggiri as a local wisdom and an identity of all communities in Lampung, both the natives and the immigrants, so that they will understand the standard values of their behavior. The dissemination of such values can bring a peaceful life. (4) Empowering the traditional institutions of piil pesenggiri because they can play a strategic role to instill the values of piil pesenggiri on peoples.

Through these four steps, piil pesenggiri is expected to be able to provide a harmony in the life of Lampung society, including the Mesuji people being involved in a land conflict. Such a harmony will gradually lead to a mutual understanding based on the local values of Lampung society. Later, the values called piil pesenggiri should serve as the social identity of Lampung people in general, and Mesuji people in particular. The identity will indicate that the Mesuji people have a peace culture which is an important capital in a civilized society. The peace culture manifested in piil pesenggiri is as follows:

The first is juluk adek. As a personal characteristic, juluk adek should also attach to members of Lampung society. This characteristic should be internalized and implemented in the 
form of social interaction every day. Juluk adek is an identity as well as a source of motivation for Lampung society to understand their rights and obligations. It must be manifested in their words and actions.

The second is nemui nyimah. This principle suggests that every family in Lampung society should maintain good mutual respect among people; that is a family should promote the principle of openness, decency and fairness. Nemui nyimah is basically based on a sense of sincerity to create harmony in family and society. Thus, this principle rejects any misconduct incompatible with the prevailing norms of social life. The concrete form of nemui nyimah in the public life today is displayed through social care and a sense of solidarity. People with such human values will be open minded and motivated to do righteous deeds for their community.

The third is nengah nyappur. This principle suggests that people of Lampung society uphold solidarity and like to make friends with anyone, regardless their race, religion, grade, origin and class. Given the pluralistic life in Lampung, it can be understood that people of this area have practiced nengah nyappur as their way of life. Nengah nyappur also encourages a high curiosity that fosters pioneering attitudes. This indicates that the Lampung people have a spirit of hard work and determination to achieve success in the future. Nengah nyappur is also a reflection of the principle of musyawarah or deliberation for social agreement. This condition requires a broad horizon, tolerance and responsibility. Therefore, people of Lampung must be able to behave properly in accordance with different conditions. They must be ready to listen, analyze and deliver information correctly.

The fourth is sakai sambayan. This principle means helping and cooperation. In this sense, the Lampung people must show 
participation and a sense of solidarity to various social activities. Conversely, they will get less respected if they are not able to participate in social activities. This behavior illustrates tolerance and togetherness. Here, someone would give anything voluntarily if he thinks it has benefits for people or community. Sakai sambayan maintains togetherness. It encourages people to help each other, especially the weak, both physically and mentally.

Piil pesenggiri as peace culture is capable of becoming an adhesive element of multicultural identity in Lampung. In this context, piil pesenggiri offers a space open for dialogue to fade any kind of conflict and exclusivism inherent in a community. It is a media that bridges various interests in land conflicts in Mesuji in order to refrain from the potentials of greater conflicts. Piil pesenggiri as an alternative of land conflict resolution is aimed to invite all conflicting parties to negotiate by utilizing cultural and emotional approach. The approach is what actually makes this model of conflict resolution different from positive law.

There is a tendency that the application of positive law in the land conflicts is somewhat compelling. It seems to be artificial and temporary, although it is legally enforceable. This can be seen, for example, from many religious anarchism cases that are resolved through legal approach, but they meet failure. Those religious cases remain unresolved. Therefore, through the internalization and actualization of piil pesenggiri as the model of conflict resolutions, a peaceful community full of togetherness and cooperation (sakai sambaian), openness and decency (nyimah), and innovation (nyapur) toward a new society (bejuluk adek) becomes possible.

Furthermore, piil pesenggiri also functions as a mechanism to prevent social disintegration in Lampung, especially in Mesuji. Its implementation is highly necessary in an effort to change the mindset of the conflicting individuals and groups in Mesuji. 
Each party should have good understanding of the values contained in Pill Pesenggiri. Therefore, it is safe to say that local wisdom is a synthesis of social, cultural and religious elements of Mesuji whose purpose is to reconcile the relationships between fellow communities which are reduced by political and economic interests, such as land conflicts (Haba 2008).

\section{Conclusion}

Various efforts to deal with land conflicts in Mesuji need to consider the potentials of local wisdom. Here, the values of local wisdom are seen as an identity inherent in social life, and, thus, conflict resolution must touch the inner side of individual or social life. Local wisdom is a peace culture that is believed to be able to function as an adhesive element in multicultural society. In the context of Lampung society, piil pesenggiri is the intended peace culture, for it has the potentials to become a model of conflict resolution based on local wisdom. Land conflicts that occurred in Mesuji of Lampung Province should involve a cultural approach, given that positive law often fails. In this sense, piil pesenggiri offers a space open for dialogue to fade any kind of conflicts and exclusivism in a community. Cultural approach is chosen to be an alternative solution to land conflicts because efforts through positive law are often compelling, artificial and temporary although such efforts have legal forces. More specifically, internalization and actualization of values contained in piil pesenggiri, such as juluk adek, nemui nyimah, nengah nyapur, and sakai sambayan, can be used as a media for land conflict resolution in Mesuji

\section{Bibliography}

Chandra, R. 1992. Konflik Dalam Kehidupan Sehari-Hari. Yogyakarta: Kanisius. 
Haba, J. 2008. "Revitalisasi Kearifan Lokal: Studi Resolusi Konflik Di Kalimantan Barat, Maluku Dan Poso." In Agama Dan Kearifan Lokal Dalam Tantangan Global, edited by Irwan Abdullah. Yogyakarta: Pustaka Pelajar.

Heynes, J. 2000. Demokrasi Dan Masyarakat Sipil Di Dunia Ketiga Gerakan Politik Baru Kaum Terpinggir. Jakarta: Yayasan Obor Indonesia.

Mandel, E. 2016. Tesis-Tesis Pokok Marxisme. Yogyakarta: Resist Book.

Mudzhar, M. A. 2003. "Pluralisme, Pandangan Ideologis, Dan Konflik Sosial Bernuansa Agama.” In Konflik Etno Religius Indonesia Kontemporer, edited by Moh. Soleh Isre. Jakarta: Puslitbang Kehidupan Beragama.

Nugroho, H. 2001. Menggugat Kekuasaan Negara. Surakarta: Muhamadyah University Press.

Soimin, S. 2008. Status Hak Dan Pembebasan Lahan. Jakarta: Sinar Grafika.

Sumardjono, M. S. W. 2008. Mediasi Sengketa Lahan, Potensi Penerapan Alternatif Penyelesaian Sengketa (ADR) D $i$ Bidang Perlahanan. Jakarta: Kompas Gramedia.

Susan, N. 2012. Negara Gagal Mengelola Konflik: Demokrasi Dan Tata Kelola Konflik Di Indonesia. Yogyakarta: Pustaka Pelajar.

Wibowo, A. 2012. “Maraknya Perampasan Lahan Rakyat.” Majalah Media Pembaharuan. 